\title{
Movimiento vecinal, urbanismo y participación en Valladolid (1970-1995): una perspectiva histórica sobre el "derecho a la ciudad"1
}

\author{
Neighbourhood movement, urban planning and \\ participation in Valladolid (1970-1995): a historical \\ perspective on the "right to the city"
}

\author{
María A. Castrillo Romón ${ }^{1}$ y Constantino Gonzalo Morell ${ }^{2}$ \\ Fecha de recepción: 21-03-2021 - Fecha de aceptación: 10-05-2021 \\ Hábitat y Sociedad (ISSN 2173-125X), n. ${ }^{\circ}$ 14, noviembre de 2021, pp. 97-115. \\ https://doi.org/10.12795/HabitatySociedad.2021.i14.06
}

\begin{abstract}
Summary
Social History and urban planning History combine in this text in order to contribute to the knowledge of the neighbourhood movement in Valladolid (Spain) in the period of its birth and greatest development (19701995). The perspective adopted axes on the concept of the "right to the city", coined by Henri Lefebvre in 1968 , and focuses the study of the conflicts hold for neighbourhood organisations face to municipal governments in the process of conquest of participation ability in all kinds of decisions on the city. The most of the sources are the local daily press, but also archival and bibliographical documents. Three periods characterised by the general climate of relations between the neighbourhood movement and the City Council structure the content of the paper, separated by two turning points: the municipal elections of 1979 and a deep rupture in 1986. The analysis shows, in one hand, continuities and changes in the role played by the neighbourhood movement in Valladolid as a "stakeholder" (in the Lefebvrian sense of the term). In the other hand, it identifies some effective conditioning factors and limitations in the conquest of the right to the city.
\end{abstract}

\section{Key words}

Urban planning; Right to the City; Social Participation; Conflict

\begin{abstract}
Resumen
La historia social se articula con la historia urbanística en este texto para contribuir al conocimiento del movimiento vecinal de Valladolid (España) en el periodo de su nacimiento y mayor desarrollo (1970-1995). La perspectiva adoptada tiene su eje en el concepto de "derecho a la ciudad", acuñado por Henri Lefebvre en 1968, y pone el foco del estudio sobre los conflictos sostenidos por las organizaciones vecinales con los gobiernos municipales en el proceso de conquista de la participación en las decisiones de todo orden sobre la ciudad. Las fuentes empleadas son, en su mayor parte, la prensa diaria local, pero también documentos de archivo y bibliográficos. El contenido del artículo se estructura en tres periodos caracterizados por el clima general de relaciones entre el movimiento vecinal y el Ayuntamiento, con dos puntos de inflexión en las elecciones municipales de 1979 y en una profunda ruptura acontecida en 1986. Se muestran así las continuidades y los cambios en el papel desempeñado por el movimiento vecinal vallisoletano como "interesado" (en el sentido lefebvriano del término) en la transformación de la ciudad a lo largo del periodo estudiado y se identifican, desde el análisis de esa experiencia histórica, algunos condicionamientos y limitaciones efectivos en la conquista del derecho a la ciudad.
\end{abstract}

\section{Pallabras clave}

Urbanismo; Derecho a la Ciudad; Participación Ciudadana; Conflicto

\footnotetext{
1 Este trabajo se enmarca en el proyecto urbanHist- History of European Urbanism in the 20th Century, financiado por la Comisión Europea (H2020-MSCA-ITN 2016, código 721933).

2 IUU-Instituto universitario de Urbanística de la Universidad de Valladolid. E-mail: mariacr@arq.uva.es. ORCID: https://orcid. org/0000-0002-2331-2854.

3 IES Juan de Juni (Valladolid). E-mail: constantinogonzalomorell@gmail.com
} 


\section{Introducción}

Hace poco más de 50 años, al tiempo que renacía el movimiento vecinal, se editaba por primera vez en España una de las obras más conocidas del filósofo Henri Lefebvre, El derecho a la ciudad, publicada en Francia en 1968:

El derecho a la ciudad no puede concebirse como un simple derecho de visita o retorno hacia las ciudades tradicionales. Solo puede formularse como derecho a la vida urbana, transformada, renovada [...]. El derecho a la ciudad se manifiesta como forma superior de los derechos: el derecho a la libertad, a la individualización en la socialización, al hábitat y al habitar. El derecho a la obra (a la actividad participante) y el derecho a la apropiación (muy diferente del derecho a la propiedad) están imbricados en el derecho a la ciudad (Lefebvre, 1978, pp. 138 y 159).

La obra de Henri Lefebvre sobre el espacio y, en particular, El derecho a la ciudad ha venido siendo objeto desde mediados de los años 1990 de un renovado reconocimiento internacional, tanto desde perspectivas teóricas (Stanek, 2011; VVAA, 2011) como desde enfoques orientados a la práctica (Demazière, Erdi, Galhardo y Gaudin, 2018; VVAA, 2020). No faltan tampoco mistificaciones, como las que pretenden que tibios procesos de participación normalizada son capaces de realizar el "derecho a la ciudad", como si este fuese disociable del "combate por la emancipación” individual y colectiva (Busquet y Garnier, 2011).

Por ello, y compartiendo cuestionamientos recientes esbozados desde la Historia urbana en torno a las movilizaciones por causa del urbanismo (Backouche et al., 2018), este artículo propone hacer de las luchas urbanas orientadas por el derecho a la ciudad un vector de interpretación histórica. Además, quiere contribuir desde la Historia urbana y urbanística a construir un conocimiento más preciso de los procesos asociados al derecho a la ciudad y, dentro de ello, del papel del conflicto y la confrontación.

El movimiento vecinal en la España de las décadas de 1970 y 1980 representa, sin duda, uno de esos casos en que colectivos populares protagonizaron una lucha por el hábitat y por el derecho a habitar, a participar, a apropiarse del espacio que habitaban y a transformar la vida urbana. De hecho, tiene un reconocimiento amplio y desde perspectivas diversas el hecho que, en muchas ciudades españolas, el movimiento vecinal (asociaciones llamadas primero "de cabezas de familia", luego "de vecinos" y actualmente "vecinales") (en adelante, AAVV) fue un agente fundamental en la evolución de la vida política y en las transformaciones urbanísticas en ese periodo (sin ánimo de exhaustividad, cfr. Pérez Quintana y Sánchez León, 2009; Domènech Sampere, 2010; Martínez Muntada, 2011; Bordetas Jiménez, 2012; Jiménez-Romera, 2013; Andreu, 2014; Contreras Becerra, 2018).

Más concretamente para el caso del movimiento vecinal vallisoletano, Gonzalo Morell (2013) ha analizado con detalle la historia desde sus orígenes y ha dado cuenta de los muchos aspectos en los que el movimiento vecinal vallisoletano desplegó su importante actividad hasta 1986. Esta amplitud y diversidad, también se aprecia en publicaciones en las que algunas organizaciones vecinales recogen su historia y la memoria de barrios (Federación AAVV Valladolid, 2005; AVV Pilarica, 2007; Anta y AVV 24 de diciembre, 2010) o, incluso, en los trabajos de memoria de otros actores políticos de la ciudad (Martínez y González, 
2013). El carácter del movimiento vecinal como agente en la transformación espacial de Valladolid ha sido largamente reconocido desde la historia y crítica urbanística (Fernández-Maroto, 2019; FernándezMaroto y Pedruelo Martín, 2019; Fernández-Maroto y Santos Ganges, 2020), subrayando en ocasiones su articulación en el marco político local (Castrillo y Santos, 2008) y su problemática relación con las políticas de participación (Castrillo et al., 2014).

El trabajo que sigue busca articular la historia social y la historia urbanística para contribuir al conocimiento del movimiento vecinal vallisoletano específicamente desde la perspectiva del derecho a la ciudad y de los conflictos asociados a su conquista. El objetivo es doble. Por un lado, se trata de cuestionar el papel desempeñado por el movimiento vecinal como "interesado" en el sentido lefebvriano (Lefebvre, 1967), es decir, como poder colectivo que actúa de forma autónoma contra unas condiciones de existencia que denuncia, en busca de una remodelación de los procesos de urbanización y, en general, de una gestión de espacio urbano en la que pueda intervenir permanente. Estudios como el de Pérez Quintana y Sánchez León (2009) para Madrid o de Gonzalo Morell (2011) para Valladolid han apuntado ya, aunque no de forma explícita, ese carácter de "interesado" adoptado por las AAVV. Este artículo lo subrayará, poniendo el acento en la cuestión de la autonomía, y, conforme a ello, también afrontará el objetivo de identificar, desde el análisis de la experiencia histórica vallisoletana, algunos condicionamientos y limitaciones efectivos en la conquista del derecho a la ciudad. Como se ha apuntado para el caso de la informalidad urbana en Madrid, las barreras a la autonomía del movimiento vecinal pueden relacionarse con el "recelo" de las instituciones ante el poder movilizador de las AAVV y su reacción en términos de "normalización" de la participación y de las actividades vecinales, y de intentos de "despolitización", esto es, de expulsión de un campo de debate y acción política que se entiende restringido a los partidos (Jiménez-Romera, 2013).

En el caso del movimiento vecinal vallisoletano, su condición de "interesado" en los procesos de urbanización y gestión de la ciudad articuló diversos conflictos que estructuraron sus relaciones con distintas instituciones y poderes públicos (ejército, Ministerio de Educación y Ciencia, INSALUD, etc.). De todos ellos, nos centraremos aquí en el Ayuntamiento de Valladolid, no solo por evidentes razones de economía sino porque es, sin lugar a dudas, el principal interlocutor público de las organizaciones vecinales de la ciudad y el destinatario de la mayor parte de sus demandas y reivindicaciones.

En definitiva, en la perspectiva de atajar interpretaciones irénicas y falseadas del derecho a la ciudad, y con el foco puesto en la discusión de las condiciones de la realización de este, analizaremos con un enfoque histórico los conflictos que, actuando de forma autónoma, encaró el movimiento vecinal vallisoletano y cómo contribuyeron a dibujar los perfiles y la evolución de las relaciones entre las AAVV y los gobiernos municipales.

El periodo propuesto para el estudio (1970-1995) arranca en el momento en que nacen y emergen en la vida pública local las AAVV; recorre el lapso convencionalmente denominado "transición española", en el que el movimiento vecinal cobrará un gran auge, y se extiende durante sus años de mayor vitalidad en Valladolid. El lapso cronológico analizado se cierra con las elecciones municipales de 1995 que, tras 16 años de gobiernos municipales presididos por Tomás Rodriguez Bolaños (Partido Socialista Obrero Español), sentenciaron el viraje a la 
4 Se ha hecho un vaciado completo de todas las portadas y de la sección Valladolid entre el 1 de enero de 1984 y el 31 de diciembre de 1995, registrando todas las noticias en que se recogía expresamente la postura de alguna AV o de la federación de AAVV en contextos de conflicto. Se ha soslayado la información sobre fiestas o eventos culturales que no tuviesen un afán reivindicativo explícito (implícitamente, siempre estaban ahí), así como las innumerables ocasiones en que las asociaciones de vecinos o la federación aparecen evocadas o convocadas por el Ayuntamiento $\mathrm{u}$ otros agentes políticos o sociales (sindicatos, partidos, asociaciones de diverso cuño, etc.).

5 Obviamente, la prensa no es un canal neutro y tiene intereses propios que pueden interferir en la comunicación de los conflictos. Sería muy interesante objetivar su papel en los contextos de confrontación vecinal, pero esto excede las posibilidades de este trabajo. derecha del Ayuntamiento y, con ello, abrieron una etapa claramente distinta para el urbanismo (De las Rivas, 2008, p. 266) y para el movimiento vecinal en Valladolid (Castrillo y Santos, 2008).

En cuanto a los aspectos metodológicos, es importante observar que este trabajo es, en cierta medida, una síntesis original de algunos resultados de la investigación doctoral de Constantino Gonzalo Morell sobre el movimiento vecinal en Valladolid entre 1964 y 1986, profusamente apoyada en fuentes archivísticas y en memorias de ciertos personajes clave, tanto del movimiento vecinal como del gobierno municipal. Pero también incorpora los materiales de una búsqueda para un lapso más extenso en la prensa diaria y, fundamentalmente, en el periódico de mayor tradición y tirada en la ciudad, El Norte de Castilla ${ }^{4}$ único que recorre todo el periodo estudiado y que se evidenciaría no solo como el espacio privilegiado de la confrontación pública entre AAVV y Ayuntamiento, donde se expresaron sus conflictos y se escenificaron las relaciones que interesan a este artículo, sino también un canal prioritario de comunicación entre las partes a lo largo de todo el periodo analizado, incluso cuando el diálogo entre ellas se rompe. ${ }^{5}$

En fin, dos importantes discontinuidades en la historia de las confrontaciones del movimiento vecinal con el gobierno local permiten estructurar este análisis en tres partes. El primer tramo temporal abarca hasta las elecciones municipales de 1979, fecha final del último gobierno municipal del franquismo. El segundo lapso comienza con la democracia local representativa y llega hasta 1985-1986, momento en el que, como veremos, se produjo una profunda crisis en las relaciones vecinales con el gobierno local. El tercer periodo, por su parte, llega hasta las elecciones municipales de 1995, que pusieron el Ayuntamiento en manos del PP.

\section{AAVV frente a ayuntamientos franquistas (1970-1979): reivindicaciones de urbanismo y de democracia representativa}

La penuria de las condiciones de vida y vivienda en Valladolid, ligada a la ausencia de canales de participación política popular, fueron determinantes del nacimiento en las asociaciones que hoy conocemos como "vecinales" (AAVV), definidas por su adscripción territorial a un barrio y encuadradas inicialmente en la Ley de Asociaciones 191/64, que regulaba y estipulaba la aparición de Asociaciones de Cabezas de Familia en el marco del Movimiento Nacional. La primera aprobada en Valladolid fue la Asociación de cabezas de familia del barrio de la Rondilla, el 24 de febrero de 1970. Tras ella y hasta 1976, se registrarían otras 10 más (Barrio Belén, Delicias, Pilarica, 4 de Marzo, Pajarillos Bajos, Santa Clara, La Victoria, Barrio Girón, Huerta del Rey y Pajarillos Altos) y, en 1979 , serían ya una veintena las que formaban la "mancha vecinal" extendida por la ciudad, como observa Gonzalo Morell, desde la periferia hacia el centro (Cfr. Gonzalo Morell, 2013, pp. 117-135).

A pesar de los pocos recursos, la baja afiliación y las condiciones impuestas por la dictadura, las AAVV construyeron una cultura asociativa bien diferenciada dentro del asociacionismo de la época, como ya reconocía el Gobierno Civil de Valladolid en 1977:

Nacidas la mayoría con un claro matiz político, han adoptado la postura de reivindicar ante los Ayuntamientos los derechos de los vecinos de 
los barrios que representan y tienen una clara actitud de crítica cuando se creen marginados por la política local. Hacen manifestaciones, encierros, sentadas ante el Ayuntamiento, asisten a los plenos de la Corporación y, sobre todo, celebran asambleas que después divulgan en la prensa sobre esas críticas y reivindicaciones (citado en Gonzalo Morell, 2013, pp. 134-135).

\section{La mejora de las condiciones del marco de vida: el inicio} de décadas de lucha por transformar el urbanismo

En la década de 1970, las movilizaciones del naciente movimiento vecinal en Valladolid estuvieron estrechamente asociadas - aunque no solo- a problemas del marco de vida. De entre los muchos ejemplos ilustrativos, quizá el más significativo por el grado de movilización que alcanzó y por su trascendencia posterior fue el protagonizado por la Asociación Familiar Rondilla, primero, desde octubre de 1976, para paralizar el Plan Parcial Ribera de Castilla, con un punto culminante en la campaña "La Ribera es nuestra" y la multitudinaria manifestación de 31 de mayo de 1978, y, después de conseguirlo, para que los terrenos ganados a la especulación inmobiliaria fuesen dedicados a dotaciones urbanísticas para el barrio (parque y equipamientos diversos) (Gonzalo Morell, 2011b; Ruiz Varona, 2013). Como en la mayoría de las reivindicaciones vecinales por el urbanismo, el periodo cubierto desde la expresión del conflicto hasta la finalización de las actuaciones asociadas a su resolución es muy largo. En el caso del Plan Ribera de Castilla, mediaron un par de décadas entre las primeras movilizaciones y las ejecuciones de la última fase del parque y de los últimos equipamientos reivindicados. Pero las dificultades y la tardanza en este proceso no fueron óbice para considerarlo un éxito desde muchos puntos de vista y que el Ayuntamiento lo erigiese tácitamente en modelo de intervención en las periferias vallisoletanas (De las Rivas Sanz, FernándezMaroto y Rodrigo González, 2019).

\section{La democracia municipal como lucha vecinal en la} década de 1970

Aunque no hay ninguna duda sobre la importancia central de las movilizaciones por problemas del marco de vida (urbanismo, vivienda, medio ambiente) desde los orígenes mismos del movimiento vecinal vallisoletano (Castrillo y Santos, 2008; Gonzalo Morell, 2013), no hay que olvidar, como subraya Anta (2020), que no fueron el único objetivo de las movilizaciones vecinales en la década de 1970. Más concretamente, en lo que se refiere a las relaciones con el gobierno municipal, es forzoso subrayar también el papel jugado por ciertas asociaciones de vecinos en la democratización del poder local (Encinas Rodríguez, 2004; Gonzalo Morell, 2013).

De hecho, la historia vecinal en Valladolid contradice la idea de que las elecciones celebradas el 25 de enero de 1976 con el objetivo de cubrir casi la mitad de las alcaldías de España no despertaron ninguna inquietud entre la opinión pública (Cfr. Orduña Rebollo, 2005). Bien al contrario, una semana antes, tres asociaciones de cabezas de familia convocaron asambleas en Valladolid para discutir la futura elección del alcalde, aunque solo una de ellas, la de las Delicias, con unos 300 participantes, decidió no reconocer al alcalde que resultase elegido y constituirse en asamblea permanente hasta que la elección de concejales y alcalde fuese más democrática, lo que fue reprimido con una astronó- 
mica multa de 100000 pesetas impuesta al presidente en funciones de la AV, Juan Antonio Cañada (Cfr. Gonzalo Morell, 2013, pp. 164-167).

Más tarde, en la campaña electoral de 1979, las AAVV desplegaron de forma generalizada una gran actividad, poniendo su amplia capacidad de convocatoria al servicio de la difusión del conocimiento de diversas candidaturas y animando al voto (Gonzalo Morell, 2013, pp. 255-273). Finalmente, las afinidades ideológicas con los partidos de izquierda y el clima general de cordialidad y colaboración construido en el objetivo común de democratizar la vida local cobraron un nuevo significado cuando las elecciones del 3 de abril de 1979 dieron la victoria al PSOE y este formó gobierno con el PCE (Berzal de la Rosa, 2000). Esos comicios resituaron al movimiento vecinal y los partidos en sus relaciones con el gobierno municipal e inauguraron una nueva etapa en las relaciones entre AAVV y consistorio.

\section{Las AAVV federadas frente a los "primeros ayuntamientos democráticos" (1979-1986): diálogos y movilizaciones}

Las elecciones municipales de 1979 supusieron un punto de inflexión en el devenir de las asociaciones de vecinos y del urbanismo en Valladolid, como en toda España (cfr. Terán, 1999, pp. 325-326). Algunos autores han subrayado la pérdida de influencia y capacidad de movilización que acusó, en términos generales, el movimiento vecinal a partir de ese momento (Alvarez Junco, 1994, p. 434), mientras que, en otros análisis, y más concretamente en el caso vallisoletano, la valoración de ese momento crítico tiende a ser más equilibrada. Aunque no se niega el desgaste que supuso el trasvase de militantes desde las asociaciones vallisoletanas a los partidos (cfr. Gonzalo Morell, 2013, pp. 287-288), también se reconoce el mantenimiento de unos niveles de actividad y movilización muy significativos, al menos, durante la década de 1980 (Castrillo y Santos, 2008; Gonzalo Morell, 2013).

De hecho, en Valladolid, las reivindicaciones vecinales y el diálogo mantenido entre las asociaciones barriales y la nueva corporación municipal fueron una pieza básica de la política local durante las primeras legislaturas, y no solo en lo referido al urbanismo, sino también en la amplia diversidad de campos en los que se desplegó la lucha vecinal, como la educación de adultos, el régimen local y la participación ciudadana, entre otras (Anta, 2020; Carasa Soto, 2005; Gonzalo Morell, 2013, pp. 164-250).

\section{La Federación provincial de AAVV "Antonio Machado", interlocutor del Ayuntamiento de Valladolid}

El 22 de febrero de 1980, tras la constitución de los nuevos consistorios, también vería la luz la Federación Provincial de Asociaciones de Vecinos de Valladolid «Antonio Machado» (en adelante, FV). La nueva entidad, que contaba con el precedente de una Coordinadora Interbarrios y que reunió inicialmente una docena de asociaciones (aunque luego pasarían de la veintena), se definió como un "órgano unitario y representativo para ser aceptado como interlocutor válido por el Ayuntamiento y tener una presencia pública definida y reconocida" (Federación AAVV Valladolid, 2005, p. 11). El principio de "un barrio, una asociación de vecinos" fue determinante en su conformación y en su 
estructura, ya que todos los barrios federados tenían representantes en la asamblea general, que era, con la junta directiva, las dos piezas clave de la arquitectura de la nueva entidad (Gonzalo Morell, 2013, pp. 135-142).

La FV, como instancia de coordinación de la práctica totalidad de las AAVV vallisoletanas, tendría representación en los consejos, fundaciones y empresas municipales y un papel fundamental en la acción del movimiento vecinal, lo que no significa que siempre consiguiese construir una postura común frente a problemas suprabarriales ni que sus decisiones concitasen una unanimidad exenta de fisuras, por más que, en principio, todas las asociaciones federadas tendían a compartir posturas ideológicas de corte progresista. ${ }^{6}$

Aunque la contribución de la FV a la proyección del movimiento vecinal vallisoletano en la esfera autonómica (CAVECAL) y española (CAVE) fue significativa (Cfr. Gonzalo Morell, 2010), la importancia del papel que desempeñó en determinadas cuestiones de alcance global para la ciudad fue fundamental. Además de ciertos asuntos que se citarán más adelante, es conveniente subrayar aquí su activa participación en la elaboración del PGOU de 1984 (Castrillo y Santos, 2008, p. 17; Federación AAVV Valladolid, 2005, p. 13; Gonzalo Morell, 2013, pp. 204205), un documento con un alto interés urbanístico (Fernández-Maroto, 2015) que, además de catalizar un importante consenso y dar soporte a la política emprendida por el Ayuntamiento en favor de la mejora de los barrios periféricos y de cierto reequilibrio del desarrollo urbano de la ciudad, resolvió casi una década de oposición vecinal a los desmesurados planes parciales previstos en el Plan General precedente (1969).

\section{Asociaciones de vecinos, reivindicaciones barriales y políticas municipales: una relación constructiva}

Como ha señalado Anta (2000), el nuevo Ayuntamiento se mostró desde el principio interesado por problema de la participación social y el primer pleno municipal ordinario (8 de mayo de 1979) creó, en ausencia de un marco regulatorio ad hoc, una Comisión especial sobre información y participación ciudadana cuyos trabajos propiciarían que, un año después, el pleno del 7 de mayo de 1981 aprobase un innovador Reglamento de participación ciudadana en el que se reconocía un papel relevante a las asociaciones vecinales. Además, el nuevo Ayuntamiento, a través de subvenciones y cesiones de locales para las asociaciones, y de la construcción, a partir de 1982, de centros cívicos en los barrios, también comenzó a paliar la precariedad de recursos en la que se había movido hasta entonces el movimiento vecinal (Gonzalo Morell, 2013, pp. 151-159).

La mejora de las condiciones de vida en los barrios de la ciudad, siquiera en lo que se refería a paliar ciertos déficits realmente abrumadores (lo que se ha dado en llamar el "urbanismo de urgencia"), fue un objetivo prioritario del Ayuntamiento de Valladolid salido de las urnas de 1979, que enfrentó decididamente muchos problemas urbanísticos que venían siendo objeto de denuncias y reivindicaciones vecinales desde tiempo atrás. En el marco de esta tarea, que se prolongaría varios mandatos, pero que, sin duda, fue absolutamente central para las corporaciones de 1979-1983 y 1983-1987, se dibujaría una buena parte de las nuevas relaciones del gobierno local con el movimiento vecinal. Ambos agentes encontrarían allí un campo de acción en el que mantuvieron un dinamismo importante durante las dos décadas siguientes.
6 Para cumplir con el objetivo de dar cuenta del movimiento vecinal en relación con el derecho a la ciudad, este artículo no diferenciará entre las reivindicaciones portadas por asociaciones federadas (la gran mayoría de las existentes hasta 1995) y las protagonizadas por las pocas AAVV que no participaban en la FV, caso, por ejemplo, de las AAVV El Páramo o Juan de Austria. 
7 Sin ningún ánimo de exhaustividad, cf. "Terrenos de Farnesio. Habrá negociación con el Ayuntamiento y los promotores", Hoja del Lunes, 08/02/1982, p. 5.; "Las obras avanzan a buen ritmo. El Parque de Farnesio: un jardín conseguido a través de la movilización vecinal”, El Norte de Castilla, 05/02/1987, p. 7.

8 Solo como muestra de los muchos documentos de prensa publicados entre 1980 y 1991: "Vecinos de La Cañada cortaron el tráfico en La Rubia. En demanda de pavimentación del barrio", $E l$ Norte de Castilla, 06/06/1980, p. 5; "'Solo aceptaremos el proyecto que nos ofrezca otra vivienda sin tener que pagar nada a cambio'. Para los vecinos de la Cañada, el Plan de Reforma del Ayuntamiento 'esconde intereses egoístas'”, El Norte de Castilla, 11/11/1986, p. 7 .

9 "Placa dedicada al Ayuntamiento en la Plaza de la Trinidad", El Norte de Castilla, 05/07/1985, p. 6.

10 Cf. "Malestar entre los vecinos de San Andrés por el retraso de las obras en la Plaza del Caño Argales", El Norte de Castilla, portada del 05/12/1985, p. 7 .

11 "Comisión Municipal permanente. Ocho millones para construir un campo de fútbol en la Zona Sur", El Norte de Castilla, 05/12/1984, p. 5; "Protesta vecinal en Huerta del Rey", El Norte de Castilla, 03/05/1985, p. 7.

12 Imposible recoger aquí todas las noticias aparecidas en la prensa que dan cuenta de estos conflictos. Valgan como muestra solo dos: "Tras la manifestación promovida ayer por diversas asociaciones del barrio. Ayuntamiento y MEC se comprometen a atajar el problema de escolarización en La Victoria”, El Norte de Castilla, 28/09/1985, p. 9; "El miércoles se manifestarán ante el INSALUD. Vecinos de Huerta del Rey y Girón reivindicaron ayer el prometido centro de Salud", $E l$ Norte de Castilla, 05/05/1986, p. 5. 13 "Julián Campo, ministro de Obras Públicas, visitó la red viaria de Valladolid. Firmado el convenio entre el Ayuntamiento y el MOPU para construir la Ronda Norte", El Norte de Castilla, $07 / 11 / 1984$, p. 9
Algunas de esas reivindicaciones vecinales se articularon, al menos en lo referido a la ordenación del suelo, a través del nuevo PGOU y bajo la clara influencia del proceso seguido con el plan parcial Ribera de Castilla. Entre los ejemplos ilustrativos puede citarse la reivindicación de la asociación de Delicias que, desde 1977, presionaba para que cesase la actividad militar en los terrenos de los cuarteles de Farnesio y para que el Estudio de Detalle previsto sobre ellos redujese su previsión de viviendas e incorporase una significativa porción de zonas verdes para uso del barrio, una aspiración que se vio finalmente culminada en 1988, cuando se inauguró el Parque de la Paz. ${ }^{7}$

La problemática específica de los barrios de urbanización marginal, se expresaría con fuerza desde 1980 en el caso de la Cañada de Puente Duero. Las primeras movilizaciones vecinales fueron por el asfaltado de la vía y, luego, por la regularización del barrio. El proceso, particularmente conflictivo, culminaría con la aprobación de un Plan Especial de Reforma Interior (PERI) y la ejecución de una serie de realojos y de un proyecto de urbanización. ${ }^{8}$

Otras intervenciones urbanísticas de menor entidad, pero significativas desde el punto de vista de reivindicaciones de ciertas AAVV también se desarrollaron en ese periodo de ebullición de los primeros años 1980, algunas con gran éxito, como la remodelación de la plaza de la Trinidad, ${ }^{9}$ y otras más problemáticas, como la remodelación de la plaza del Caño Argales, cuyas obras se prolongaron hasta $1986 .{ }^{10}$

La construcción de equipamientos barriales que caían dentro de las competencias municipales (culturales, deportivos...) también fue objeto de reivindicaciones vecinales. ${ }^{11}$ Pero, en este campo, los conflictos más agudos los mantuvo el movimiento vecinal frente a otras administraciones. En particular, entre 1980 y 1987 fueron especialmente intensas sus confrontaciones con Ministerio de Educación y Ciencia, y el INSALUD para paliar los graves déficits en muchos barrios de centros escolares y de salud, respectivamente. ${ }^{12}$

En otros casos las denuncias vecinales se dirigieron hacia asuntos en los que competencias municipales se entremezclaban con las de otras entidades públicas, como el problema del tráfico pesado, incluido el de mercancías peligrosas, que atravesaba el casco urbano generando molestias y riesgos muy importantes en ciertos barrios. Las movilizaciones se multiplicarían desde principios de los años 1980 pero las soluciones solo empezarían a encauzarse lentamente y en sus aspectos más graves a partir de 1984, cuando el Ministerio de obras públicas y urbanismo (MOPU) firmó un convenio con el Ayuntamiento para construir la Ronda Norte, ${ }^{13}$ el primer tramo de la primera de las dos vías de circunvalación de la ciudad previstas en el PGOU aprobado ese mismo año y finalizadas 30 años más tarde, en 2014.

Entre los conflictos en torno al urbanismo, hay uno desatado en 1984 por el PERI Juan de Austria que presenta un perfil particular. La reordenación de los terrenos del antiguo estadio municipal de fútbol, situado en uno de los principales ejes de expansión de la ciudad —el Paseo de Zorrilla—, acogerá viviendas, espacios libres de uso público, un centro cívico, una conexión con la otra margen del Pisuerga y, lo que fue más problemático, el primer establecimiento en Valladolid de una conocida marca de grandes almacenes. Este asunto, que se saldaría a favor del Ayuntamiento y la empresa de distribución, movilizó a organizaciones muy diversas, entre ellas, la asociación de comerciantes y dos asociaciones vecinales: la AV Reina Juana, de la Zona Sur, federa$\mathrm{da}$, con una larga trayectoria y un papel relativamente discreto en este 
conflicto; y la AV Juan de Austria, nacida como escisión de la anterior y portadora de una actitud mucho más activa contra el PERI. ${ }^{14}$

Por último, las relaciones entre el gobierno municipal electo en 1979 y las AAVV también se desarrollaron en un campo de acción local que, si bien requería de espacios específicos (y, en eso, involucraba las competencias urbanísticas del Ayuntamiento), presentaba el grueso de su problemática en el campo de la gestión. Iniciativas vecinales muy valoradas, como la educación de adultos, las actividades culturales (como el teatro en Delicias) o las casas de cultura, concitaron el apoyo municipal a través de subvenciones e infraestructuras - principalmente centros cívicos- dependientes de la Concejalía de Cultura y la Fundación municipal homónima. Pero también propiciaron el conflicto, a veces con niveles de tensión muy altos, en torno a la participación de las AAVV en el gobierno de las actividades que ellas mismas habían gestado. Este es el caso, por ejemplo, de la dura confrontación de la AV Delicias con la administración municipal por mor de la programación de la Casa de cultura del barrio ${ }^{15}$ o de la educación de adultos ${ }^{16}$ dos claras muestras de procesos en los que la cooperación del consistorio se tornó, en buena medida, para el movimiento vecinal, en desposesión de iniciativas que habían construido y puesto en marcha (Gonzalo Morell, 2013, pp. 212-218).

\section{Más allá de los barrios y del urbanismo local: del conflicto a la ruptura de relaciones}

Algunas AAVV y, sobre todo, la FV vallisoletana se pronunciaron y fueron muy activas durante los primeros años 1980 en algunos asuntos que rebasaban los límites de los barrios y del urbanismo local, y que se situaban en la órbita de oposición a ciertas políticas. Algunos solo comportaron niveles discretos de movilización, como la contestación en 1984 y 1985, respectivamente, de los proyectos de Ley de bases del régimen local ${ }^{17}$ y de fuerzas y cuerpos de seguridad del Estado. ${ }^{18}$ Sin embargo, hubo otros que suscitaron durísimas confrontaciones con el gobierno municipal y un enconamiento que acarreó consecuencias graves y duraderas en el clima de relaciones mutuas.

La primera por orden cronológico fue detonada por la entrada de España en la OTAN. Una parte significativa de las AAVV vallisoletanas tomó postura en contra, de forma coherente con el pacifismo y antimilitarismo que profesaban y en continuidad con protestas precedentes contra determinadas prácticas o intereses del ejército en los barrios. ${ }^{19}$ La movilizaciones contra la OTAN se iniciaron con una serie de conferencias auspiciadas por las asociaciones de vecinos de Pajarillos y de la Zona Sur en 1981, se extendieron al momento en que la FV consiguió el apoyo del XIII Encuentro de Asociaciones de Vecinos del Estado Español, celebrado en 1982 en esta ciudad, acompañaron las sonadas protestas contra la celebración en Valladolid del Día de las Fuerzas Armadas de 1984 y, finalmente, quedarían zanjadas con el referéndum sobre la permanencia de España en la OTAN del 12 de marzo de $1986 .{ }^{20}$ La victoria fue para el "sí" que propugnaban los gobiernos local y estatal (PSOE). El Comité Anti-OTAN, en el que participaban muy activamente varias organizaciones vecinales, encajó la derrota y la FV dio por zanjado el asunto, al punto de desestimar públicamente cualquier posibilidad de prolongación en una nueva organización de oposición política. ${ }^{21} \mathrm{El}$ esfuerzo desarrollado a favor del "no" y el revés que supuso el inesperado resultado de la consulta desembocó en un
14 Son numerosísimas las noticias que dieron cuenta en la prensa de las confrontaciones en torno a este PERI, desde El Norte de Castilla, 30/05/1984, p. 5, hasta 14/05/1987, p. 11.

15 "El Centro Cívico Delicias contará con una fuerte representación vecinal", El Norte de Castilla, 15/11/1986, p. 7;

"Mantienen diferentes criterios sobre la composición del Equipo Directivo. Ayuntamiento y vecinos, enfrentados por el control del Centro Cívico de Delicias”, El Norte de Castilla, 04/12/1986.

16 "En Valladolid hay 20000 analfabetos. Los Colectivos de EPA denuncian el abandono de la Formación Permanente de adultos", El Norte de Castilla, 01/11/1984, p. 5; "Ayudas del Ayuntamiento para la Educación Permanente de Adultos", El Norte de Castilla, 24/05/1985, p. 8 .

17 Cfr., por ejemplo, "Los vecinos presentarán sus propuestas a los portavoces parlamentarios. La ley de bases del Régimen local no propicia la participación de los ciudadanos", El Norte de Castilla, 02/05/1984, p. 6.

18 Cfr., por ejemplo, "La FAAVV reivindica una policía civil”, El Norte de Castilla, 29/11/1985, p. 9.

19 Uno de los más conflictivos sería el paso de convoyes por el barrio de las Delicias y, más tarde, por Pajarillos. Cf. El Norte de Castilla, portada del domingo $19 / 05 / 1985$; 14/07/1985, p. 6; 12/11/1985, p. 7; 07/12/1985, p. 10; 26/01/1986, p. 11;09/05/1986, p. 7.; y 04/09/1986, p. 5.

20 Cfr., entre otras, "Actos contra la entrada de España en la O.T.A.N.”, El Norte de Castilla, miércoles 8 de julio de 1981, Valladolid, 1981, p. 6. Federación de AAVV de Valladolid, Las Asociaciones de Vecinos, hoy. XIII Encuentro Estatal de Asociaciones de Vecinos. Valladolid: 5-6 junio 1982, Federación de AAVV de Valladolid, Valladolid, 1982, p. 10.

21 "Aunque sus miembros tratarán de mantener la unidad de la campaña. La Coordinadora Anti-OTAN de Valladolid no generará una organización política estable", El Norte de Castilla, 15/03/1986, p. 8 . 
22 Solo a título de ilustración: "En la manifestación del domingo. Unas diez mil personas, contra el aumento de los impuestos municipales", El Norte de Castilla, 15/05/1984, p. 8.

23 "La unanimidad no existió a la hora de la reducción de los gastos. El Ayuntamiento aprobó la suspensión del Recargo Municipal”, El Norte de Castilla, 04/05/1985, p. 5.

24 "Tras la supresión del recargo municipal. Discrepancia a la hora del recorte presupuestario", El Norte de Castilla, domingo 05/05/1985, p. 8.

25 "Las AA.VV. estudian las medidas a adoptar ante el requerimiento para el pago del Recargo Municipal", El Norte de Castilla, domingo 19/05/1985, p. 8.

26 "La oposición al recargo municipal, motivo de la ruptura. El Alcalde no quiere volver a hablar con la Federación de Vecinos", El Norte de Castilla, 07/06/1985, p. 5 .

27 "El Ayuntamiento, dispuesto a dialogar con los vecinos si cesan sus ataques injustificados", El Norte de Castilla, $12 / 06 / 1985$, p. 6.

28 "Se restablece el diálogo entre el Ayuntamiento y la FV", El Norte de Castilla, portada del 27 de junio de 1985, Valladolid, 1985, p. 1.

29 Cfr. "Carta al alcalde", El Norte de Castilla, 09/06/1985, p. 6, entre otros.

30 Como muestra, vid. "El próximo día 10 se reúnen representantes de la FEMP y del Ministerio. Hacienda no ha decidido todavía cómo se llevará a cabo la devolución del recargo municipal”, Domingo 05/01/1986, p. 5.

31 Valga aquí como muestra de este proceso la primera de las noticas al respecto: "La FV advierte que el incremento de la contribución urbana es de un 300 por ciento", El Norte de Castilla, portada del 16/09/1984, p. 9.

32 "El Ayuntamiento no cambiará los presupuestos- 87 y espera que el Estado se haga cargo de su déficit. La devolución de la contribución urbana ascenderá a mil setecientos millones", El Norte de Castilla, 19/02/1987, p. 5. cierto desencanto de la transición política, tanto entre el movimiento vecinal de Valladolid como en España (Gonzalo Morell, 2011a; Gonzalo Morell, 2013, pp. 228-233). Además, en la medida en que la posición política del PSOE - y, con él, del Ayuntamiento de Valladolid-varió, entre 1981 y 1986, del célebre "De entrada, no" a la petición del sí en el referéndum sobre la permanencia de España en la OTAN, también es expresivo de la construcción de una divergencia política importante a nivel local entre el movimiento vecinal y el gobierno municipal.

De manera casi simultánea con lo anterior, la FV tuvo que encarar otro conjunto de duros conflictos frente al Ayuntamiento -en este caso, resueltos a favor de las tesis vecinales- en torno a cuestiones relacionadas con la gestión de la hacienda local y las fuentes de financiación municipal. Los desencuentros de ambos agentes en estos campos habían surgido ya en 1979, pero sería a partir de 1984 cuando se suscitaría la cuestión que terminaría sentenciando el futuro de las relaciones entre consistorio y movimiento vecinal: el recargo sobre la cuota líquida del IRPF que el gobierno central articuló como potestad de los ayuntamientos para hacer frente a sus endémicos problemas de financiación.

La FV de Valladolid, como otras organizaciones vecinales en Castilla y León y en España, entendió que esta era una medida fiscal regresiva y que los problemas de las haciendas municipales para hacer frente a los gastos de prestación de los servicios debían ser resueltos a través de la mejora y estabilización de las trasferencias del Estado a los ayuntamientos. Por ello, organizó toda una campaña en contra de la decisión del Ayuntamiento de Valladolid de establecer un recargo del 3,5\% sobre la declaración del IRPF de 1983 y, luego, sobre la de 1984. Tras una intensísima campaña vecinal de movilizaciones de todo tipo durante varios años consecutivos, ${ }^{22}$ el 3 de mayo de 1985, el pleno municipal aprobó suspender el recargo previsto sobre la declaración del IRPF de 1984 y, al mismo tiempo, previó una importante reducción de gastos municipales. La FV señaló que la reiteración en proponer reducciones "como consecuencia de la supresión del recargo" parecía contener un cierto ánimo intimidatorio, de chantaje al vecindario o de soterrada descalificación de las AAVV. ${ }^{23}$ También denunció en prensa ser objeto de una "contra campaña" del equipo de gobierno municipal, cuando lo que debería hacerse era "la necesaria planificación y programación de las decisiones y actuaciones municipales" ${ }^{24}$ De hecho, la FV no se conformó con la victoria parcial y se mantuvo firme en sus movilizaciones contra el recargo en la declaración de $1983 .{ }^{25} \mathrm{El}$ alcalde Rodríguez Bolaños respondía, en junio de 1985, con unas declaraciones en prensa en las que anunciaba su decisión de no volver a hablar con el ente federado y de remitirle, en lo sucesivo, al concejal de relaciones ciudadanas. ${ }^{26}$ Esta decisión (matizada pocos días más tarde por el primer teniente alcalde, ${ }^{27}$ revocada al mes siguiente, ${ }^{28}$ y respondida vigorosamente por la $\mathrm{FV}^{29}$ ) marcó simbólicamente el inicio del declive de las relaciones entre ambas instituciones.

La tensión se reagravaría en enero de 1986, cuando el Tribunal Constitucional respaldó las tesis vecinales y declaró ilegal el recargo sobre el IRPF de 1984, lo que se desencadenó una nueva guerra de declaraciones públicas, ${ }^{30}$ y más aún al año siguiente, en febrero de 1987, cuando salió la sentencia contra el recargo de la contribución territorial urbana, denunciado por la FV desde $1984,{ }^{31}$ que obligó al Ayuntamiento a devolver 1700 millones de pesetas. ${ }^{32}$ Para ese entonces, ambos contendientes coincidían ya expresamente en que la solución al grave 
problema hacendístico de los municipios españoles pasaba, como había defendido el movimiento vecinal desde el principio, por garantizar una financiación adecuada para los Ayuntamientos desde los presupuestos del Estado. Aun así, no consiguieron colaborar en este objetivo y, en el camino hasta la promulgación de la Ley 39/1988, de 28 de diciembre, reguladora de las Haciendas Locales, aun se registraron varios desencuentros entre ellos. ${ }^{33}$

Otro duro conflicto se suscitó en los mismos años por la decisión del Ayuntamiento de construir en el barrio de Arturo Eyries el pabellón polideportivo Pisuerga para acoger en Valladolid el Campeonato mundial de gimnasia rítmica de $1985 .{ }^{34}$ Desde el primer momento, la iniciativa suscitó la oposición de la FV, que lo consideraba un gasto innecesario e inconveniente. Pero el conflicto se agravó cuando el proyecto requirió de financiación suplementaria y de un endeudamiento municipal extraordinario. La FV impugnó en 1985 y 1986 varias decisiones municipales al respecto ${ }^{35}$ y recurrió a la vía judicial contra una gestión económica que, además de sospechosa de prácticas incorrectas ${ }^{36}$ era el soporte de una "política de grandes obras" que contestaban porque conllevaba una relegación de las ordinarias, más cercanas a las necesidades defendidas por el movimiento vecinal. ${ }^{37}$

\section{De la participación vecinal a las políticas municipales de participación (1986-1995)}

En noviembre de 1986, nueve meses después de la gran crisis desatada a inicios del año entre el movimiento vecinal y el Ayuntamiento de Valladolid, ambas partes volvían a manifestar su voluntad de acabar con el "periodo gélido" 38 y recuperar unas relaciones normalizadas. ${ }^{39}$ Sin embargo, nunca más recobrarían el clima de concordia que habían conocido anteriormente. De hecho, en la década siguiente, son muchos los momentos en que la prensa se hace eco de una gran acritud. Por ejemplo, en diciembre de 1988, la FV declaraba que el grupo municipal socialista "se estaba derechizando"; en la primavera siguiente, cuatro de las AAVV más veteranas, incluida Rondilla, "ponían en evidencia la gestión municipal" y, en otoño, el alcalde se ausentaba de la primera audiencia pública convocada en la ciudad, en Rondilla. ${ }^{40} \mathrm{~A}$ principios de 1991, pocos meses antes de las elecciones municipales, un estudio realizado por la FV establecía que la "insatisfactoria gestión municipal socialista" había "hecho perder la ilusión al movimiento vecinal". ${ }^{41}$ Con todo, en 1992, la valoración general que hacía el presidente de la FV de las tres legislaturas municipales tenía un sesgo indulgente ("Bolaños se ha relajado, pero con el PP hubiera sido peor"). ${ }^{42}$ Sin embargo, el titular de un reportaje publicado en un suplemento especial de El Norte de Castilla la víspera de las elecciones de 28 de mayo de 1995, cuando el PSOE perdió el gobierno municipal, era contundente: "Vecinos: la otra oposición". ${ }^{43}$

Para las asociaciones de vecinos, el pico de tensiones con el gobierno municipal alcanzado en 1986 parece haber tenido un reflejo en ciertos conflictos internos ${ }^{44} \mathrm{y}$, sobre todo, podría haber producido un cierto desgaste y haber pesado en la voluntad de algunas asociaciones de replegarse sobre asuntos urbanísticos y barriales. De hecho, la asamblea anual de la FV de 1986 acordó que ese fuese el año del urbanismo en Valladolid y que se pusiese en marcha una comisión estable en esa materia. Según el periódico, también "se habló de volver a los oríge-
33 Cfr. El Norte de Castilla, 10/02/1988, p. 5. y $01 / 11 / 1988$, p. 7.

34 Cfr. "En una sesión pendiente de los ruegos y preguntas. Aprobación de importantes asuntos en el pleno municipal", El Norte de Castilla, 07/09/1984, p. 5.

35 Cfr. "La FV recurre a la vía jurídica por las obras del nuevo polideportivo", portada de El Norte de Castilla, $22 / 08 / 1985$ y p. 5 .

36 Una de muchas noticias al respecto sería: "Alegaciones de la FAAVV al Ayuntamiento y al Tribunal Económico-Administrativo. Impugnado el acuerdo de financiación del presupuesto de las obras del Polideportivo", 29/08/1985, p. 6 37 La FV denunciaba en 1985 la existencia de "dos máquinas administrativas": la de los "grandes proyectos", "no hay nunca problema económico, todo se realiza dentro de los plazos, etc." y las otras obras (Ronda, Polideportivo de Canterac, Plaza Caño Argales...). Cfr. "'Por prácticas presupuestarias incorrectas del Ayuntamiento'. La FAAVV recurre a la vía jurídica por la obras del nuevo Polideportivo", 22/08/1985, p. 5.

38 "Primeros pasos para la constitución de las 'asociaciones de vecinos y usuarios'. Policía, carretera de Ronda y enseñanza, frentes de batalla de los vecinos de cara al otoño", El Norte de Castilla, 25/09/1986, p. 10 .

39 "El Ayuntamiento y la FV tratan de normalizar sus relaciones", portada de $E l$ Norte de Castilla, domingo 09/11/1986. 40 Cf. El Norte de Castilla, 23/12/1988, p.7; 16/06/1989, p.5; y 07/10/1989, p.7. 41 Cf. El Norte de Castilla, 08/01/1991, p.5; y 25/02/1991, p. 5.

42 El Norte de Castilla, 31/03/1992, p. 5.

43 El Norte de Castilla, 27/05/1995, p. 16.

44 Cf. "La Asociación Huerta del Rey podría querellarse contra un grupo de vecinos", El Norte de Castilla, 10/07/1986, p. 7. 
45 Cf. "A pesar de que en la Federación Provincial muchos consideran que es una tarea estéril. Los vecinos decidieron continuar su participación en las empresas y fundaciones del Ayuntamiento", El Norte de Castilla, 11/02/1986, p. 8

46 "Los vecinos presentarán sus propuestas a los portavoces parlamentarios. La ley de bases del Régimen local no propicia la participación de los ciudadanos", El Norte de Castilla, 02/05/1984, p. 6 47 "A pesar de que en la Federación Provincial muchos consideran que es una tarea estéril. Los vecinos decidieron continuar su participación en las empresas y fundaciones del Ayuntamiento", El Norte de Castilla, 11/02/1986, p. 8.

48 "El domingo, asamblea anual de la Federación. El ministro Almunia apoya la 'utilidad pública' de las asociaciones de vecinos", El Norte de Castilla, 20/02/1987, p. 7.

49 Declaraciones de la FV en El Norte de Castilla, 24/04/1985, p. 6.

50 "La primera que se pondrá en marcha será la de Delicias. La participación vecinal en los asuntos municipales se hará a través de las Juntas de Distrito", El Norte de Castilla, 24/04/1985, p. 6.

51 "Las AAVV elaboran un documento sobre la labor del Ayuntamiento. Primeras críticas a 4 años de gestión municipal: escasa participación y personalismo", $E l$ Norte de Castilla, 10/01/1987, p. 10.

52 "Las asociaciones de vecinos de Valladolid podrían asumir la defensa de los consumidores", El Norte de Castilla, 03/07/1986, p. 3.

53 Cf., entre otras, El Norte de Castilla, 09/09/1988, p. 8; 16/11/1988, p. 9; 08/02/1989, p. 5 .; y 09/03/1989, p. 9.

54 Cf. El Norte de Castilla, 27/11/1988; 29/11/1988, p. 12; y 26/12/1989, p. 5 . nes del movimiento vecinal en cuanto a partir de unas reivindicaciones base sobre urbanismo y presionar desde la calle con movilizaciones, ya que por ahora el diálogo con la Administración no parece dar resultados positivos". ${ }^{45}$

\section{Paradojas de la lucha por la participación. La institucionalización de una política municipal de participación, ¿ordenar o limitar?}

Como señala Gonzalo Morell (2013, pp. 152-155), al igual que la llegada de Rodríguez Bolaños a la alcaldía supuso el establecimiento de ayudas municipales para las AAVV, tras la crisis de 1985 estas se redujeron notablemente, lo que produjo no pocas quejas. Pero, en este contexto, también resultó notorio el renovado interés del Ayuntamiento por reorganizar la política de participación ciudadana municipal y, con ello, sus relaciones formales con el mundo asociativo.

Para las AAVV, la participación formal en la política municipal era un asunto que había revestido interés, pero que se había ido cubriendo de decepción. Tras tres años de rodaje, la presencia en comisiones ejecutivas de empresas y fundaciones municipales prevista en el Reglamento de participación ciudadana de 1981 era valorada como "de resultados inciertos", aunque les proporcionaba más información "que si esa presencia no se hubiese conseguido" ${ }^{46}$ Sin embargo, en 1986, ya era juzgada como "estéril". ${ }^{47}$

Con ocasión de la discusión de la Ley de Bases del Régimen Local la prensa recogió una visión vecinal de la participación en la vida municipal. Debía ser propiciada en ese escalón porque era "el más cercano al ciudadano" y debía ser configurada como un derecho colectivo, sin detrimento de que también tuviese carácter individual. Las AAVV debían tener voz en los órganos de la administración local y la posibilidad de presentar mociones y de disfrutar de una declaración de utilidad pública de forma análoga a las asociaciones de consumidores. ${ }^{48}$

Pero la ley aprobada en 1985 ("sin haber modificado sus aspectos más regresivos y negativos para los vecinos y Asociaciones” ${ }^{49}$ ) constituyó un marco legal alejado de esos intereses. El Ayuntamiento de Valladolid activó sus previsiones en materia de participación ese mismo año, comenzando por las Juntas de Distrito ${ }^{50}$ pero, al final de la legislatura, la valoración del movimiento vecinal era que la participación había sido "escasa" ${ }^{51} \mathrm{El}$ contexto parecía tan poco favorable que la propia FV intentará conseguir una mejor posición por medio de la asunción de la condición de asociación de consumidores. ${ }^{52}$

El principal conflicto en torno a la política de participación ciudadana lo desató, en 1988, la elaboración de un nuevo reglamento municipal en la materia. Iniciada en septiembre y bloqueada durante meses por la negativa de Rodríguez Bolaños a que los vecinos tuvieran voto en los órganos de gobierno de fundaciones y sociedades municipales, su resultado nunca satisfizo a la FV. ${ }^{53}$ En particular, fue especialmente tormentosa la cuestión de la participación vecinal en la gestión de la Fundación municipal de cultura, ${ }^{54}$ que ya había concitado intereses encontrados incluso cuando las relaciones con el Ayuntamiento atravesaban mejores momentos.

Finalmente, los espacios conseguidos por el movimiento vecinal para participar formalmente en las entidades municipales no fueron muy importantes, pero, por un lado, se obtuvieron en órganos de decisión (no en consultivos) y, por otro lado, fue una participación con voz 
y voto. Sin embargo, la FV solo disfrutaría plenamente de los magros frutos de esa lucha hasta 1995, cuando el PP llegó al gobierno municipal (Castrillo y Santos, 2008, pp. 61-62).

\section{Después del "urbanismo de urgencia": la complejidad de la problemática de los barrios y la gestión urbanística global de la ciudad}

Desde 1986, la voluntad expresa del movimiento vecinal de volver a centrarse sobre los problemas del urbanismo es perceptible. No abandonó el seguimiento de asuntos de la hacienda local, como el cobro indebido de contribución urbana a los beneficiarios de viviendas sociales en alquiler, la revisión de los valores catastrales, las contribuciones especia$\operatorname{les}^{55} \mathrm{u}$ otros, pero nunca volvió a concederles un protagonismo central.

El trabajo de la FV tenderá a retomar algunos temas urbanísticos con un alcance global para la ciudad, como la construcción de la ronda. ${ }^{56}$ Pero, sin duda, el asunto urbanístico y ambiental que suscitó un mayor conflicto en los albores de la década de 1990 fue la construcción de un vertedero de residuos tóxicos de la empresa CETRANSA en Santovenia de Pisuerga, municipio limítrofe con Valladolid. Desde 1991, se multiplicaron las movilizaciones en contra del proyecto y se creó una coordinadora de la que formaron parte tanto la FV de Valladolid como la AV "Calle Real" de Santovenia. ${ }^{57}$ Pese a todo, la Junta de Castilla y León aprobaría el proyecto en 1992 y, en 1993, la instalación entró en funcionamiento. Las denuncias de la coordinadora prosperaron hasta el Tribunal Supremo (que, en 2002, declaró ilegales las instalaciones) y hasta el Tribunal Constitucional, que también sentenció en contra en 2013.

También a partir de los años 1990, es apreciable que algunos asuntos relacionados con equipamientos sociales de carácter global produjeron momentos de crisis interna en la FV, ya sea por divergencias irreconciliables, como en el caso del proyecto de "Ciudad humanitaria" o "macrocentro" de la Cruz Roja" (Gonzalo Morell, 2013, pp. 141), o, en casos menos sonados, por la dificultad de conciliar los intereses de distintas AAVV para construir una postura como federación. ${ }^{58}$

Simultáneamente, cada AV continuará trabajando por la mejora de su barrio dentro de los márgenes del "urbanismo de urgencia" ya mencionado, que todavía eran bastante amplios a mediados de la década de 1980. Más allá de la falta de centros educativos que ya se ha mencionado, eran muchas las demandas relativas a necesidades básicas de los barrios que seguían entonces insatisfechas, como testimoniaban informes emitidos por varias AAVV en $1986 .{ }^{59}$ Esas deficiencias (que continuarían originando reivindicaciones a lo largo de todo el periodo estudiado) variaban en función de la situación de cada barrio: equipamientos básicos de salud, culturales, deportivos, para ancianos o guarderías, además de espacios libres y la urbanización o reurbanización de calles y plazas. Entre la miríada de este tipo de reivindicaciones recogidas en la prensa local entre 1986 y 1995, destacan algunos conflictos de mayor complejidad, como el de la cerámica Silió, en el barrio de los Vadillos, que fue el origen de la AV Vicente Escudero y que se saldó con el traslado de la fábrica y la reordenación de la parcela liberada, incluyendo una nueva plaza $;^{60}$ o el caso del Mercado central, en el barrio de Pajarillos, ${ }^{61}$ que llegaría a convertirse en Centro cívico integrado zona Este. También resulta bastante característico de este periodo la multiplicación de conflictos relacionados con la movilidad, no solo
55 Cf. El Norte de Castilla, 15/09/1994, p. 11 y $26 / 11 / 1994$, p. 7.

56 Cf. El Norte de Castilla, 02/07/1986, p.9; 25/09/ 1986, p. 10; 01/09/1991, p. 10; 24/11/1991, p. 13 .

57 Las noticias en prensa son muchísimas. Solo en El Norte de Castilla, y sin ánimo de exhaustividad, cf. 25/11/1991, p. 5; 30/11/1991, p. 5; 05/12/1991, p. 9; 21/12/1991, p. 5; 26/01/1992, p. 5; 03/02/1992, p. 9; 14/03/1992, p. 5 у p. 7; 15/03/1992, p. 25; 16/03/1992, p. 7;09/09/1992, p. 9;07/03/1995, p. 5; $04 / 05 / 1995$, p. 5 , etc.

58 El "frente vecinal" se rompería, por ejemplo, en el caso del centro de transeúntes, cuando cinco AAVV afectadas definieron separadamente una postura conjunta (Cf. El Norte de Castilla, 11/06/1989, p.10; 14/11/1989, p. 9; y 30/04/1990, p. 5) y también en relación con la propuesta de instalar un centro para toxicómanos en el barrio de la Pilarica (Cf. El Norte de Castilla, 07/08/1993, p. 5; 11/11/1993, p. 7; y 12/11/1993, p. 9).

59 Por ejemplo, "La AVV presenta un dossier sobre el descalabro urbanístico en el barrio de Pajarillos", El Norte de Castilla, 09/05/1986, p. 7, o El Norte de Castilla, 04/09/1986, p. 5.

60 Cfr. El Norte de Castilla, 05/05/1992, p. 11; 09/05/1992, p. 11; 14/03/1993, p. 10. 61 Cfr. entre otros, "Las fiestas reivindicativas de los Pajarillos han dado su primer fruto. El alcalde anuncia que el Mercado Central se trasladará al Polígono San Cristóbal”, El Norte de Castilla, 29/06/1986, p. 7. 
62 Sin ánimo de exhaustividad, cfr. El Norte de Castilla, 21/05/1986, p. 8; 02/05/1993, p. 10.

63 Por ejemplo, para Rondilla, cfr. El Norte de Castilla, 10/09/1986, p. 7 y 31/12/1988, p. 7. En 1991, se generaliza la discusión sobre aparcamientos para residentes en régimen de cooperativa (cfr. El Norte de Castilla, 07/02/1991, p. 5). 64 Cfr. El Norte de Castilla, 09/12/1987, p. 5.

65 "No se cierra por ahora el paso a nivel de La Pilarica. El Ayuntamiento estudia la posibilidad de construir el ferrocarril subterráneo", El Norte de Castilla, 26/02/1987, p. 9 .

66 "Abierto a todos los ciudadanos. Concurso de ideas para la recuperación del trazado urbano del ferrocarril”, El Norte de Castilla, 06/06/1984, p. 6

67 Cfr. El Norte de Castilla, 18/09/1985, p. $9 ; 05 / 08 / 1986$, p. $10 ; 14 / 07 / 1988$, p. $10 ; 04 / 12 / 1989$, p. $5 ; 26 / 04 / 1990$, p. $9 ;$ y 27/08/1990, p. 5.

68 Cfr. El Norte de Castilla, 02/05/1985, p. 8 .

69 Cf. El Norte de Castilla, 15/04/1987, p. 5; 11/10/1989, p. 7.

70 "Los vecinos quieren su estructura actual. El barrio España no está satisfecho con las mejoras que se pretenden en el PERI", El Norte de Castilla, 02/07/1986, p. 9.

71 "Ayuntamiento y Asociación de Vecinos estudian un plan para mejorar el urbanismo del barrio. El rescate de zonas abiertas en la Rondilla podría exigir la demolición de varias manzanas", El Norte de Castilla, 29/09/1986, p. 5.

72 Cfr., entre otras, "Los vecinos de la segunda fase de Huerta del Rey se oponen a la construcción de 800 viviendas sociales", El Norte de Castilla, portada 02/08/1985 (y p. 5).

73 "La Asociación 'Pisuerga' abordó el tema de las viviendas sociales en una asamblea", El Norte de Castilla, $30 / 09 / 1985$, p. 7.

74 Cfr., por ejemplo, "Ni viviendas sociales, ni escuelas", El Norte de Castilla, 05/02/1986, p. 11; "El problema de las viviendas sociales fracasa por la inexistencia de servicios paralelos", El Norte de Castilla, 15/09/1987, p. 5. por los problemas de tráfico y su gestión, ${ }^{62}$ sino también por la necesidad de aparcamientos para residentes ${ }^{63}$ y las deficiencias de ciertas infraestructuras viarias fundamentales para los barrios, como el acceso a La Overuela ${ }^{64}$ o el paso del ferrocarril en la Pilarica. ${ }^{65}$ Esta última cuestión era en realidad reveladora de un problema de mucho mayor calado, como era el tratamiento del paso del ferrocarril por Valladolid, que ya se había vislumbrado antes ${ }^{66}$ y no dejará de agravarse hasta el día de hoy, originando momentos realmente críticos para la FV en los primeros años del siglo XXI.

Como consecuencia de la aprobación del PGOU de 1984, se produjo también, desde los últimos años ochenta, una cascada de planes especiales de reforma interior en barrios de origen informal y, ligado a ello, una intensa actividad vecinal en la colonia del Pinar de Antequera $^{67}$ y los barrios de Pajarillos ${ }^{68}$ Buenos Aires ${ }^{69}$ o España,${ }^{70}$ entre otros. Aunque, en conjunto, como sagazmente observa Fernández Maroto (2019), la acción urbanística del Ayuntamiento, a partir de 1987:

Frente a la lógica anterior de actuar en los barrios y para los barrios, se fue virando hacia una lógica equivalente en apariencia, pero muy diferente en el fondo, consistente en actuar junto a los barrios - la ubicación como compensación - para satisfacer necesidades que cada vez iban siendo más ajenas —o cuanto menos colaterales-a los vecinos del entorno (p. 283)

Como hipótesis, podría avanzarse que la progresiva consecución de los objetivos del llamado "urbanismo de urgencia" fue dejando paso, en el contexto ya de los años noventa, a dos situaciones barriales y vecinales bien diferenciadas, pero que comparten el hecho de dejar ver la enorme complejidad de los problemas que quedaban por resolver.

Una de esas situaciones podría ilustrarse con el caso de la Rondilla, donde la AV fue adentrándose en cuestiones que requerían transformaciones espaciales cada vez más sofisticadas y complejas de gestionar, que podían requerir demoliciones significativas de lo ya existente..$^{71}$ La otra remite a las dificultades añadidas por problemas que tenían un calado estructural y que estaban relacionados con el profundo abismo social abierto por el deterioro global de la situación socioeconómica (reestructuración productiva e incremento del paro) y la extensión del "problema de la droga" y la delincuencia a ella asociada, cuyo estigma recayó principalmente sobre la población gitana. Esta compleja problemática se reflejaría en todos los barrios, pero tuvo un especial impacto en algunos muy concretos, aunque a través de vías distintas. Una de ellas sería la construcción de nuevas viviendas sociales y, más concretamente, la iniciativa anunciada por la Junta de Castilla y León en 1985 de ubicar 800 de ellas en terrenos de la segunda fase del Plan parcial de la Huerta del Rey. Dos asociaciones reaccionarían frente a este proyecto. La AV "Huerta del Rey" se opondría desde el principio de forma rotunda, ${ }^{72}$ mientras que la AV "Pisuerga" adoptaría una posición más matizada, insistiendo en que el problema no era la construcción de viviendas sociales sino la gestión global que se hiciese del asunto, especialmente la atención social de los posibles conflictos. ${ }^{73}$ En los años siguientes, las movilizaciones, dirigidas a la administración regional y al Ayuntamiento, fueron en contra de la mala calidad de las viviendas construidas y de las enormes deficiencias de los servicios sociales que deberían atender las necesidades especiales de las familias beneficiarias, ${ }^{74} \mathrm{y}$ reclamaban 
una revisión del Plan Parcial ${ }^{75}$ que desembocaría en el Plan Especial Huerta del Rey aprobado en 1992.

Pero, con todo, el foco de problemas sociales que más eco tuvo en la prensa y que más duramente repercutió sobre una AV se localizó sobre el barrio de Pajarillos ${ }^{76}$ y, más concretamente, sobre el Poblado de la Esperanza. A mediados de los años 1980, esta barriada municipal construida una década antes para realojar a la población chabolista que estaba asentada en el borde SE del barrio, ${ }^{77}$ daba señales de un temprano declive edificatorio $^{78}$ al tiempo que iba quedando marcada en el imaginario público por la lacra de la "inseguridad ciudadana y las drogas". Aunque la FV insistió en que era necesario ir a los orígenes del problema, ${ }^{79}$ la atención de las administraciones se dirigió a su síntoma más visible y lacerante, el poblado. En febrero de 1987, alcanzaban un acuerdo (contestado por la AV) para demoler todas las viviendas y realojar a las familias afectadas. ${ }^{80} \mathrm{El}$ proceso merecería un estudio detallado que no es posible hacer aquí y que se extralimitaría del lapso cronológico propuesto. Baste con apuntar que los derribos se prolongarían durante 24 años, ${ }^{81}$ que los realojos a ellos vinculados fueron extremadamente problemáticos ${ }^{82}$ y que, entre tanto, durante los primeros años 1990, el "problema de la droga" no dejó de agravarse y, con él, las tensiones sociales y vecinales que suscitaba (coordinadora anti-droga, patrullas ciudadanas...). ${ }^{83}$

\section{El derecho a la ciudad visto desde la historia del movimiento vecinal}

Aunque el derecho a la ciudad sigue siendo un horizonte inalcanzado a día de hoy, la historia del movimiento vecinal vallisoletano evidencia momentos de una efectiva "intervención de los interesados", con sus múltiples intereses y de forma colectiva, en la gestión de la ciudad y en la remodelación de los procesos de urbanización, es decir, momentos en que el derecho a la ciudad ha conocido un cierto grado de realización.

La historia del movimiento vecinal en Valladolid muestra cómo un colectivo popular se constituyó en un poder autónomo capaz de influir en el urbanismo y en la vida urbana de sus barrios y de toda la ciudad. Es, en este sentido, la historia de la lucha por el derecho a la ciudad, un derecho que todavía hoy sigue pareciendo muy lejano, por más que vivamos tiempos de exaltación de la "participación ciudadana".

El conflicto y la movilización se han revelado como elementos fundamentales en los procesos protagonizados desde la década de 1970 por las AAVV de Valladolid para la mejora de la ciudad y sus barrios. El análisis de las confrontaciones que mantuvieron con el Ayuntamiento también ha dejado ver que, en el fondo, subyacen dos entendimientos distintos de la participación y una tensión irresuelta en tormo a la relación entre democracia directa y democracia representativa. Esto, que no parece haber sido una particularidad del movimiento vecinal vallisoletano, se expresa, sin embargo, en Valladolid de una forma extraordinariamente neta y explícita.

Desde su nacimiento, las AAVV vallisoletanas se constituyeron como un poder colectivo que actuaba de forma autónoma contra unas condiciones de existencia que denunciaba y que no se limitaban al entorno físico urbano, sino que iban mucho más allá, desplegándose sobre toda la complejidad de la vida política y social de la ciudad. Su comportamiento en tanto que "interesado" revela el profundo alcance de esta noción y el
75 Cf. El Norte de Castilla, 05/04/1986, p. 10; 19/03/1987, p. 7; y 17/05/1987, p. 9. 76 Desde luego, no fue el único. La prensa también deja vislumbrar el agudo acrecentamiento de las desigualdades y la exclusión social en otros barrios populares como Delicias (Cfr. El Norte de Castilla, 26/01/1987, p. 7) y la Victoria (poblado chabolista del Camino del Obregón, cfr. El Norte de Castilla, 31/03/1988, p. 7). 77 Aunque los términos del realojo de los chabolistas de San Isidro estuvieron fijados por el pleno municipal desde 1971 (Cfr. El Norte de Castilla, 22/10/1971, p. 7), el Ayuntamiento no promovió el proyecto de construcción de 110 viviendas de realojo hasta 1978 (Archivo Municipal de Valladolid, Exp. 367/1978. Signatura C. 2876-1, 2877-1, 2878-1).

78 Así lo atestiguan los proyectos de reparación de viviendas de 1986 (Archivo Municipal de Valladolid, Exp. 2857/1986. Signatura C. 14482-1, 14483-1) y de rehabilitación del Centro Social Gitano de 1988 (Archivo Municipal de Valladolid, Exp. 1076/1988. Signatura C. 14200-1) 79 Cfr. El Norte de Castilla, 01/06/1985, p. 8.

80 "Todas las instituciones implicadas en el proyecto se comprometen a realojar a las 140 familias del poblado. El barrio gitano de La Esperanza será borrado del mapa antes de diez años", El Norte de Castilla, 11/02/1987, p. 5. "Los vecinos de Pajarillos, contra la solución oficial al poblado gitano", El Norte de Castilla, 21/02/1987, p. 10.

81 "Desparece el 'supermercado de la droga' de La Esperanza tras 24 años”, $E l$ Norte de Castilla, 18/01/2003, hemeroteca digital.

82 Cfr. por ejemplo, El Norte de Castilla, $10 / 10 / 1991$, p. 5 y p. $7 ; 08 / 11 / 1991$, p. $10 ; 11 / 12 / 1994$, p. 3; 06/05/1995, p. 3. 83 Cfr, entre otras, El Norte de Castilla, $01 / 10 / 1991$, p. $5 ; 25 / 10 / 1991$, p. 10 ; 19/12/1991, p. 12; 14/01/1992, p. 5; 20/03/1993, p. 10. 
carácter crucial de la autonomía. El contenido de sus denuncias y reivindicaciones, desde la democracia hasta el urbanismo o la hacienda local, no estuvo prefigurado ni contenido dentro de los límites previstos por ningún otro agente, y las importantes transformaciones que consiguieron inducir sobre las políticas urbanas y urbanísticas de Valladolid fueron el resultado de una trabajosa conquista que no siempre pudo encauzarse por la vía de la negociación con el poder.

El análisis realizado muestra que las trayectorias para la realización de esos destellos del derecho a la ciudad estuvieron fuertemente condicionadas por la actitud de las instituciones del poder político (el gobierno municipal, en primera instancia) y por los intereses de los partidos políticos, en particular, el que ostentaba la mayoría en el pleno del Ayuntamiento.

Mientras los conflictos expresados por las AAVV se ciñeron a los problemas de los barrios y del urbanismo, campos donde el poder municipal reconocía legitimidad al movimiento, las reivindicaciones de este llegaron a ser consideradas y articuladas entre las decisiones del gobierno local, al punto de llegar a modelar su política de mejora urbanística de las periferias. Por el contrario, cuando la confrontación extravasó esos campos hacia otros que, afectando igualmente a la vida de los vecinos, tenían un vínculo menos directo con el espacio urbano y más cercano al campo de acción de los partidos políticos (fiscalidad, gestión de la hacienda municipal, política de defensa...), la legitimación y la posibilidad de negociación quedó acompasada estrictamente con los intereses de estos últimos. Mientras sus posiciones estuvieron en sintonía (caso de la exigencia de elecciones democráticas o de la interpretación temprana de la relación que España debía mantener con la OTAN), los partidos no discutieron la legitimidad de la injerencia del movimiento vecinal en asuntos estrictamente políticos. Por el contrario, cuando el movimiento vecinal, en el mismo ejercicio de su autonomía y también con un amplísimo respaldo de movilización popular, adoptó posiciones encontradas con los intereses de las instituciones del poder político (caso de la salida de España de la OTAN o de las fuentes de financiación municipal), les negaron la legitimidad y cercenaron las vías de negociación hasta el punto de romper relaciones.

Es en el momento de conflicto sobre el recargo municipal donde la historia del movimiento vecinal en Valladolid evidencia con nitidez incomparable el carácter inestable y advenedizo del reconocimiento del derecho a la ciudad por parte del poder (en este caso, local). El texto publicado por la ejecutiva provincial del PSOE en 1986, tras la primera victoria judicial de las posiciones vecinales en aquel conflicto, no podía ser más claro a este respecto: denunciaba que el movimiento vecinal había tomado postura "sobre cuestiones más propias de partidos políticos (OTAN, actitudes antimilitares...) que de asociaciones vecinales" y no había querido diferenciar "la actividad vecinal de la política" y practicar "cada una en el lugar adecuado". ${ }^{84}$ En definitiva, la historia de las AAVV de Valladolid viene a confirmar lo que subrayaba J. P. Garnier (2011) en relación con el derecho a la ciudad: "la conclusión de H. Lefebvre es, a este respecto, rotunda: una transformación de la sociedad supone la posesión y la gestión colectivas del espacio por la intervención permanente de los 'interesados' con sus intereses múltiples e incluso contradictorios; por lo tanto, la confrontación”.

84 "El PSOE sale al paso de la Federación de Asociaciones de vecinos por sus críticas al Ayuntamiento ", El Norte de Castilla, 15/01/1986, p. 8 . 


\section{Referencias bibliográficas}

Álvarez Junco, José (1994). Movimientos sociales en España: del modelo tradicional a la modernidad postfranquista. En Laraña, Enrique y Gusfield, Joseph (eds.). Los nuevos movimientos sociales: de la ideología a la identidad (pp. 413-442). Madrid: CIS.

Andreu, Marc (2014). El moviment ciutadà i la transició a Barcelona: la FAVB (1972-1986) [Tesis doctoral] Universidad de Barcelona, Barcelona, España. Recuperado el 7 de enero de 2021 de: http:/ / diposit. ub.edu/dspace/bitstream/2445/54543/1/MAA_ TESI.pdf.

Anta, Jesús y Asociación de vecinos 24 de diciembre (2010). Historia del barrio Belén. Valladolid. Valladolid: Ediciones técnicas y culturales-Valladolid. Recuperado el 9 de mayo de 2021 de: https:/ / drive.google. com/file/d/0B2RxG8jpOI7rMzI4ZWJjYjctYTRiMi00 NTE4LTk4YzEtODlhOGVjMTZkZGIy/view.

Anta, Jesús (2020, 16 de diciembre). Las asociaciones vecinales en Valladolid: dos aniversarios [Entrada de blog]. La mirada curiosa. Recuperado el 7 de enero de 2021 de: https:/ /jesusantaroca.wordpress. com/2020/12/16/las-asociaciones-vecinales-en-valladolid-dos-aniversarios/.

Asociación de vecinos Pilarica (2007). Pilarica. Un barrio de Valladolid con otra historia. Valladolid: Asociación de vecinos Pilarica.

Backouche, Isabelle, Lyon-Caen, Montel, Nathalie, Theis, Valérie, Valdelorge, Loïc y Vorms, Charlotte (2018). La ville est à nous ! Aménagement urbain et mobilisations sociales depuis le Moyen Âge. Paris: Éditions de la Sorbonne.

Berzal de la Rosa, Enrique (2000). El despertar de la vida política. En Martínez, Julio (Ed.), La Transición en Valladolid. 1974-1982 (De las huelgas de FASA al Mundial de Fútbol) (pp. 69-89). Valladolid: Difácil. Recuperado el 9 de mayo de 2021 de: http:/ / repositorio.historiarecienteenlaeducacion.com/items/ show/1400.

Bordetas Jiménez, Iván (2012). Nosotros somos los que hemos hecho esta ciudad. Autoorganización y movilización vecinal durante el tardofranquismo y el proceso de cambio político [Tesis doctoral]. Universitat Autònoma de Barcelona, Barcelona, España. Recuperado el 7 de enero de 2021 de: https:/ /ddd.uab.cat/pub/tesis/2011/hdl_10803_96186/ivj1de1.pdf.

Busquet, Grégory y Garnier, Jean Pierre (2011). Un pensamiento urbano todavía contemporáneo. Las vicisitudes de la herencia lefebvriana. Urban (2011), 2 "Espectros de Lefebvre / Spectres of Lefebvre" (pp. 41-57). Recuperado el 9 de mayo de 2021 de: http:/ / polired.upm.es/index.php/urban/article/ view/1490/1986.

Carasa Soto, Pedro (2005). Cuando los vecinos se mo- vilizan, la ciudad avanza. En Federación de asociaciones de vecinos de Valladolid. 25 años haciendo ciudad. 19802005 (pp. 5-8). Valladolid: Federación de asociaciones de vecinos.

Castrillo Romón, María A. y Santos Ganges, Luis (2008). Urbanisme et militantisme de quartier dans les quartiers populaires de Valladolid. Espaces et sociétés, 2008/3(134). 53-66. DOI : 10.3917/esp.134.0053.

Castrillo, María, Jiménez, Marina, Lalana, José Luis y Santos, Luis (2013). "Derecho a la ciudad" vs "participación ciudadana”. La rehabilitación urbana y el rol de los habitantes desde la perspectiva de los vecinos militantes de los barrios de Valladolid (España), 1970-2013. En 40 anos de democracia(s): progressos, contradições e prospetivas. Actas do VIII Congresso Português de Sociologia. Lisboa, Associação Portuguesa de Sociologia. Recuperado el 7 de enero de 2021 de: https://associacaoportuguesasociologia.pt/viii_congresso/VIII_ACTAS/VIII_COM0292.pdf.

Contreras Becerra, Javier (2018). Movimiento vecinal y movimiento andalucista. Construcción de la ciudadanía y aprendizaje democrático en Andalucía (1963-1987) [Tesis doctoral]. Universidad de Granada, Granada, España. Recuperado el 7 de enero de 2021 de: https:/ / digibug.ugr.es/handle/10481/54494.

De las Rivas Sanz, Juan Luis (2008). Ayuntamiento y urbanismo. En Merino Estrada, Valentín y Orduña Rebollo, Enrique (eds.). La ciudad de Valladolid y su Ayuntamiento: 100 años de historia común (pp. 271294). Valladolid: Ayuntamiento de Valladolid.

De las Rivas Sanz, Juan Luis, Fernández-Maroto, Miguel y Rodrigo González, Enrique (2019). Reconstruire la ville en démocratie. Le cas de Valladolid dans l'Espagne des années quatre-vingt : participer, récupérer, urbaniser. Ponencia leída en el Coloquio internacional Récits de ville: usages de l'histoire et changement urbain/Relatos de ciudad: narración y usos de la historia en el cambio urbano (6 y 7 de junio de 2019). Ivry-sur-Seine (Francia).

Demazière, Christophe, Erdi, Gülçin, Galhardo, Jacques y Gaudin, Olivier (2018). 50 ans après : actualités du droit à la ville d'Henri Lefebvre. Métropolitiques, 5 décembre 2018. Recuperado el 7 de enero de 2021 de: https:/ / metropolitiques.eu/50-ans-apres-actualitesdu-droit-a-la-ville-d-Henri-Lefebvre.html .

Domènech Sampere, Xavier (Ed.) (2010) Expediente: Movimiento vecinal y cambio político, Historia del presente, 15 (2010/1), 5-76. Recuperado el 7 de enero de 2021 de: http:/ / historiadelpresente.es/sites / default/files/revista/articulos/16/historiapresente16-2010.pdf.

Encinas Rodríguez, David (2004). El final del régimen franquista y los Ayuntamientos: el colapso legal y la 
difícil convivencia del consistorio vallisoletano con la democracia. En Encinas Rodríguez, David (Ed.), La transición a la democracia en España: actas de las VI Jornadas de Castilla-La Mancha sobre Investigación en Archivos (Vol. 2, p. 3). Guadalajara: Confederación de Asociaciones de Archiveros, Bibliotecarios, Museólogos y Documentalistas; ANABAD; Asociación de Amigos del Archivo Histórico Provincial de Castilla La Mancha. Recuperado el 7 de enero de 2021 de: http:/ / biblioteca2.uclm.es/biblioteca/ceclm/websCECLM/transici\%C3\%B3n/PDF/01-03.\%20Texto. pdf.

Federación de Asociaciones de Vecinos de Valladolid (2005). 25 años haciendo ciudad. 1980-2005. Valladolid, Federación de asociaciones de vecinos. Recuperado el 7 de enero de 2021 de: https:/ / www.vecinosvalladolid.org/IMG/pdf/25_aniversario.pdf.

Fernández-Maroto, Miguel (2015). El Plan General de Valladolid de 1984. En los orígenes de un nuevo modelo urbano. Ciudades, 18, 255-263. DOI: https:/ / doi.org/10.24197/ciudades.18.2015.255-263

Fernández-Maroto, Miguel (2019). Modelo urbano y ciudad construida. Una aproximación a las inercias de la planificación urbanistica reciente en España a través del caso de Valladolid (1979-2012) [Tesis doctoral]. Universidad de Valladolid, Valladolid, España. Recuperado el 7 de enero de 2021 de: http:/ / uvadoc.uva.es/ handle/10324/37925.

Fernández-Maroto, Miguel y Pedruelo Martín, Eduardo (Eds.) (2019). Del plan al plano: 50 años de urbanismo en Valladolid, 1969-2019. Exposición, del 9 de octubre de 2019 al 30 de mayo de 2020. Valladolid: Universidad de Valladolid, Instituto de Urbanística; Ayuntamiento de Valladolid, Archivo Municipal de Valladolid.

Fernández-Maroto, Miguel; Santos y Ganges, Luis (2020). Ayuntamiento de Valladolid, transición democrática y transformación urbana: cambios de rumbo y nuevas estrategias urbanisticas (1979-1995). Valladolid: Universidad de Valladolid, Instituto universitario de Urbanística. Recuperado el 9 de mayo de 2021 de: http://uvadoc.uva.es/handle/10324/46191.

Garnier, Jean Pierre (2011). Del derecho a la vivienda al derecho a la ciudad: ¿de qué derechos hablamos... y con qué derecho? Biblio 3W, Revista Bibliográfica de Geografia y Ciencias Sociales, XVI (909). Recuperado el 7 de enero de 2021 de: http:/ /www.ub.edu/geocrit/ b3w-909.htm.

Gonzalo Morell, Constantino (2010). Una visión global del movimiento asociativo vecinal regional durante la Transición: 1970-1986. Estudios humanísticos. Historia, 9, 195-220. DOI: http://dx.doi.org/10.18002/ ehh.v0i9.

Gonzalo Morell, Constantino (2011a). El movimiento vecinal español frente a la OTAN: el caso de Valladolid. Historia 396. 1(2), 247-263. Recuperado el 9 de mayo de 2021 de: https://dialnet.unirioja.es/servlet/articulo? codigo $=3795071$.
Gonzalo Morell, Constantino (2011b). El movimiento vecinal como modelador del urbanismo: el caso de Valladolid en la Transición y la campaña "La ribera es nuestra". Studium: Revista de humanidades, 17, 303325. Recuperado el 9 de mayo de 2021 de: https:/ / dialnet.unirioja.es/servlet/articulo? codigo $=4221794$.

Gonzalo Morell, Constantino (2013). Democracia y barrio: el movimiento vecinal en Valladolid (1964-1986). Valladolid: Universidad de Valladolid.

Jiménez-Romera, Carlos (2013). Espacios de informalidad y movimientos sociales en Madrid, 1968-2011, Bitácora urbano-territorial, 23(2), 3-12. Recuperado el 7 de enero de 2021 de: https:/ / revistas.unal.edu.co/ index.php/bitacora/article/view/42039.

Lefebvre, Henri (1967) en Lefebvre, Henri, Balladur, Jean y Ecochard, Michel, L'urbanisme aujourd'hui. Mythes et réalités. Débat entre Henri Lefebure, Jean Balladur et Michel Ecochard. Les Cahiers du Centre d'Études Socialistes, 72-73. Paris: Centre d'Études Socialistes.

Lefebvre, Henri (1978). El derecho a la ciudad (4a edición). Barcelona: Península. Edición original en francés: (1968) Le droit à la ville. Paris: Anthropos. Martínez Muntada, Ricard (2011). Movimiento vecinal, antifranquismo y anticapitalismo. Historia, trabajo y sociedad, 2, 63-90. Recuperado el 7 de enero de 2021 de: https://dialnet.unirioja.es/servlet/ articulo? codigo $=3798873$.

Martínez, Julio y González, Manuel (2013). Ciudad y crisis: una conversación con Manuel González. Valladolid: Fuente de la Fama.

Orduña Rebollo, Enrique (2005). Historia del Municipalismo Español. Madrid: Iustel.

Pérez Quintana, Víctor y Sánchez León, Pablo (Eds.) (2009). Memoria ciudadana y movimiento vecinal, Madrid 1968-2008. Madrid: Libros de la Catarata.

Ruiz Varona, Ana (2013). Urbanismo y participación ciudadana: el caso de La Rondilla en el Valladolid de los años setenta. Estudios Geográficos, 74(275), 611637 DOI: https://doi.org/10.3989/estgeogr.201322.

Stanek, Lukasz (2011). Henri Lefebure on Space. Architecture, Urban Research, and the Production of Theory. Minneapolis: University of Minnesota Press.

Terán, Fernando de (1999). Historia del urbanismo en España III: siglos XIX y XX. Madrid: Cátedra. Recuperado el 9 de mayo de 2021 de: http:/ / oa.upm.es/23186/.

VVAA (2011). Espectros de Lefebvre / Spectres of Lefebvre. Urban, 2 (monográfico). Recuperado el 24 de junio de 2021 de: http:/ / polired.upm.es/index. $\mathrm{php} /$.

VVAA (2020). Derecho a la ciudad: aportes y avances para su ejercicio. Bitácora Urbano-Territorial, 30(1) (monográfico). Recuperado el 24 de junio 2021 de: https://revistas.unal.edu.co/index.php/bitacora/issue/view/5179. 
Castrillo Romón, María A. y Gonzalo Morell, Constantino (2021). Movimiento vecinal, urbanismo y participación en Valladolid (1970-1995): una perspectiva histórica sobre el "derecho a la ciudad". Hábitat y Sociedad, 14, 97-115.

<https://doi.org/10.12795/HabitatySociedad.2021.i14.06>

$\bigcirc$ 


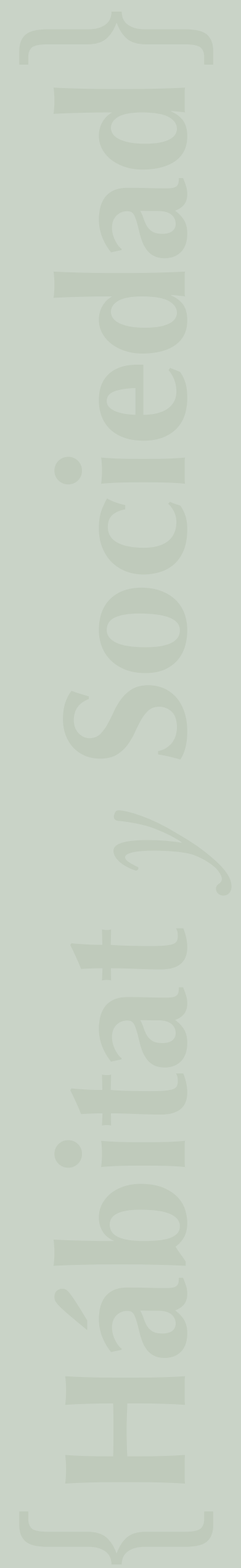

